\title{
The expected impacts of regulating non-financial reporting
}

\author{
Karen Maas, Peter Sampers
}

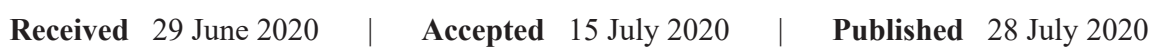

\begin{abstract}
Traditional financial reporting is not sufficient anymore for the renewed need for information of stakeholders. In result, governments have created different policies to stimulate or to have seen a strong rise in this kind of reporting during the last decades. Stakeholders, including governments, have high expectations about the potential of the reporting process to lead to improved transparency and accountability as well as to internal change and performance improvement. In this article we have developed a theory of change, describing the logic of the path from reporting to performance improvement. Based on a literature study we have collected data that support or argue against this logic line. We conclude that there is limited evidence that we can expect that reporting automatically leads to improved performance. There is a clear need for more research into the impact of non-financial reporting on performance.
\end{abstract}

\section{Relevance to practice}

With the introduction of legal requirements for non-financial reporting the questions becomes acute whether these will enhance the quality of information that is produced or whether they will hinder innovation and experimentation and result in a drive towards compliance. Empirical evidence is inconclusive but does point to certain trends and developments that may shape future reporting and performance.

\section{Keywords}

non-financial reporting, impact, CSR performance

\section{Introduction}

With the increasing interest in sustainability, society holds organizations accountable by claiming that organizations have social, environmental and economic impacts on society (Maas and Liket 2012; Frías-Aceituno et al. 2013). In result, organizations developed corporate social responsibility (CSR) activities and policies. CSR is seen as the business contribution to sustainable development (Commission of the European Communities 2002). Building on generic definitions of sustainable development (WCED 1987) it denotes a situation in which firms combine their economic goals with taking responsibility for their ecological and social impact. The social, environmental and economic impacts of business on society can be both intended or unintended, positive or negative and short term or long term (Wainwright 2002). Conse- quently, stakeholders such as consumers, media, governments and activists want to understand the way organizations deal with ethical, environmental and social issues. They want organizations to be accountable for their environmental and social effects (Schaltegger et al. 2019). In result, organizations provide their stakeholders with information on the organization's responsibility for the environment and society, or in other words, on their sustainability impact.

Traditional financial reporting is not sufficient for this renewed need for information of stakeholders (Cheng et al. 2014; Kamp-Roelands 2011; Wallage 2011). Consequently, we have seen a strong rise in non-financial reporting ${ }^{1}$ during the last decades. The increased attention for transparency, accountability and true value are only a few of the trends that have stimulated organizations to develop and publish a non-financial report. Also, govern- 
ments have created different policies to stimulate or to mandate sustainability reporting by organizations in their jurisdictions (Van der Esch and Steurer 2014). Stakeholders, including governments, have high expectations about the potential of the reporting process to lead to improved transparency and accountability as well as to internal change (European Commission 2014a; 2015). In October 2014 the EU published the EU Directive of Non-Financial Information and Diversity (Directive 2014/95/EU). This directive is a response to the need for companies to improve their reporting of environmental and social information. The end of 2016, the Dutch government translated this directive into national law. Consequently, since 2017 the Dutch government requires compliance with this directive for all organizations with more than 500 employees. This directive was initiated by the European Commission because they believed there was a need to improve the disclosure of social and environmental information by organizations. It is expected to "increase transparency by increasing the quantity of information available, to increase companies' performance, to increase accountability, and to enhance the efficiency of capital markets" (European Commission 2014). These changes are deemed to result in social, environmental and human rights impacts ('performance'). However, it is not immediately clear whether the implementation of this mandate will actually lead to the desired effects. The language in the EU directive is clearly showing lack of supporting evidence ('...could encourage boards...', ‘... is likely to trigger...') (European Commission 2015).

We use a so-called Theory of Change (ToC) to highlight the plausible pathways through which resources translate into outcomes (Jordan 2010). A ToC makes explicit what is often implicit. Being explicit about the ToC behind (mandatory) non-financial reporting helps to monitor the working and effect of the financial reporting on performance improvement. Therefore, the research question of this article is as follows:

What is the Theory of Change (ToC) behind non-financial reporting and what academic evidence is available for the various steps towards the expected performance improvement?

A visualization of the Theory of Change (ToC) of non-financial reporting describing how actions lead to effects is provided in Figure 1. The ToC runs from input to impact. This causal chain, also referred to as the 'impact value chain', distinguishes between the resources used for an action (input); the action itself (also referred to as project or activity or intervention or program); the immediate quantitative synthesis of the action (output); the direct changes in people, organizations, natural and physical environments, and social systems and institutions (outcome), along with highest order effects of the action (impact) (Clark et al. 2004; Liket et al. 2014).

Figure 1. Theory of Change of non-financial reporting (Based on Maas and Vermeulen 2015)

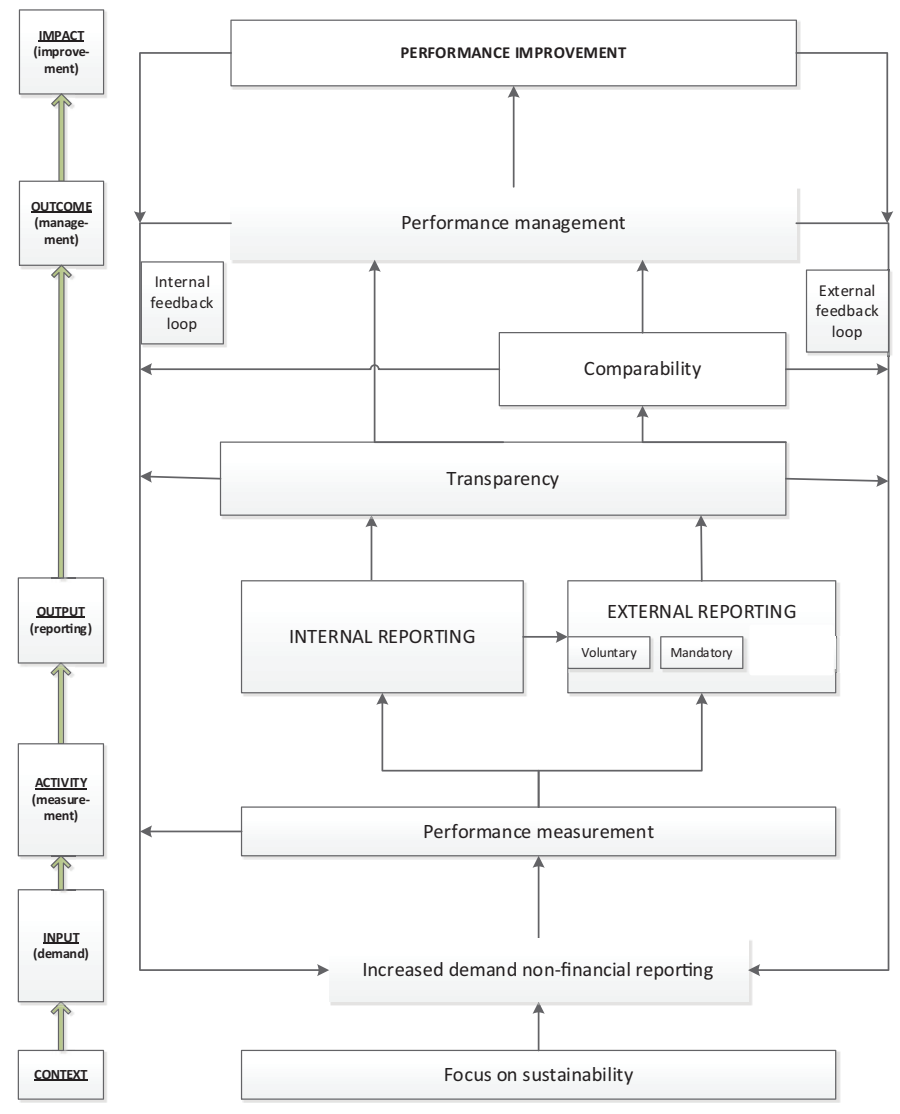


The ToC is build upon expectations reflected in practical documents like policy documents supporting the EU directive (European Commssion 2015) and the EU Directive itself (European Commission 2014a). The ToC shows that it is expected that increased demand for non-financial reporting will lead to performance measurement or assessment of non-financial data that will be used for internal and/or external reporting purposes. External reporting might be obligated through legislation, might be mandatory in another way, or could be produced voluntarily. Reporting leads to more transparency and in specific circumstances to more comparability (Jeffrey and Perkins 2014). Stakeholders, like customers or investors, might use the comparability to select a preferred organization which in turn could lead to differences in competitiveness and thereby in firm value. Comparability might also lead to internal strategy development in response to the non-financial data. This strategy might be translated in adapted management accounting and control systems to improve non-financial performance ultimately resulting in performance improvement. Based on a literature research we have collected articles that provide theoretical or empirical evidence on (the connection between) the different steps in the ToC.

The structure of this article is as follows. In section two we describe the path from an increased demand of non-financial reporting to reporting. Following, in section three the pathway from reporting to performance improvement is described. Finally, conclusions are addressed in section four.

\section{From increased demand to reporting}

\subsection{Increased demand for non-financial reporting}

To live up to the expectations of stakeholders, corporations need to approach their activities in a more strategic way and rethink the social impact of their activities (Maas and Boons 2010). CSR can become a strategic activity in two ways. Firstly, CSR is a strategic activity when the results of the measurement and monitoring of the added values are incorporated in management decisions (Maas et al. 2016). Secondly, CSR is strategic when it is integrated in the strategy of the organization (Grayson and Hodges 2004). CSR leads to sustainable production processes and/or improved existing or newly created sustainable products, services or goods. When an organization takes responsibility and is transparent about the results of their CSR approach through non-financial reporting, this influences the organizations' reputation (Bebbington et al. 2008) and stakeholder satisfaction (Swift 2001). In economic terms benefits of CSR information can arise through capital market benefits when that information is relevant for capital market participants and real effects when the information influences decisions and policies of the firm (Churet and Eccles
2014; Kim et al. 2019). However, these benefits do not come for free because corporate disclosures are costly (Christensen et al. 2019).

\subsection{Performance Measurement}

For decades, organizations have reported on their financial results and clear and robust guidelines exist for financial reporting. Nowadays, there is an increasing focus on non-financial reporting. For example, sustainability reporting is a listing requirement in South Africa (GRI 2011). In line with this, it is no surprise that in the last two decades non-financial reporting practices have made enormous progress (Christofi et al. 2012). However, although the non-financial practices have made progress, in contrast to the financial reporting guidelines the existing non-financial guidelines do not lead to comparable results, there is a lot of heterogeneity (Christensen et al. 2019; De Cambour et al. 2019; European Commission 2020).

The economic crisis of 2009 has underscored that the behavior and the main principles of society have to change (King 2011). Society (such as government, citizens, employees and other stakeholders) increasingly expect organizations to bear responsibility for the social and environmental impact of their activities (Eccles and Krzus 2010; Maas 2011). There is a need for corporate information and transparency concerning the social and environmental aspects of corporate behavior (GarcíaSánchez et al. 2013; Keeble et al. 2003; Gray et al. 1988). Next to that, organizations start to realize that transparency could have a positive effect on their business and lead to better reputation. Consequently, an increased number of organizations measure and report their non-financial performance. In most cases, the organizations that measure and report on non-financial information have a longterm vision and take sustainability seriously (Eccles et al. 2012). Moreover, it is argued that sustainability reporting increases the awareness in organizations about their role in society (Kolk 2004).

There are several reasons why sustainability reporting has received much attention from organizations, governments and agencies. Organizations operate in a multi-dimensional world, in which both financial and non-financial issues are important. Transparency became the key to 'doing well' (Eccles and Krzus 2010; Prado-Lorenzo and Garcia-Sanchez 2010). To make successful decisions, both investors and organizations need information about value drivers (Krzus 2011). Non-financial reporting also contributes to stakeholder dialogues (GRI 2002) and is not only a 'license to operate' (Kolk 2004), it is a method of corporate branding as well (Lindgreen and Swaen 2010). In addition, referring to a study of UNEP from 1998, Kolk (2004) argued that interviews with reporters and non-reporters show that sustainability reporting is expected to improve transparency, credibility and awareness (Kolk 2004). Similar benefits were reported by investors and executives interviewed by McKinsey (Bernow et al. 2019). 


\subsection{Internal and external non-financial reporting}

Non-financial reporting can be valuable for both internal use and external use. Internally it will help organizations to reconsider their management decisions and (sustainability) strategy. Externally, it helps organizations to meet the requirements of external stakeholders. Organizations can use a separate sustainability report in order to be transparent and accountable to their stakeholders.

Although non-financial reporting has received much attention, the quality of non-financial information reported is neither always informative nor sufficient from a user perspective. While accountability, transparency and legitimacy of the organization is becoming more important for both organizations and stakeholders, organizations do not always deliver the information stakeholders ask for. In many cases there is a gap between the information required by stakeholders and the information reported by organizations (Eccles and Serafeim 2011; Cheng et al. 2014; Kamp-Roelands 2011; Wallage 2011).

There are several non-financial reporting standards, such as the Global Reporting Initiative's Guidelines, UN Global Compact, OECD Guidelines for multinational organizations, CDP Ratings, Sustainability Accounting Standards Boards (SASB), International Integrated Reporting Council (IIRC) framework on Integrated Reporting and the German-European Deutsche Vereinigung für Finanzanalyse und Asset Management / European Federation of Financial Analysts Societies standard (DVFA/ EFFAS). These guidelines have improved the quality of sustainability reports significantly (Lozano 2013). Nevertheless, due to the use of these different standards, the lack of comparability between sustainability reports is still present (Barker and Eccles 2018; Eccles and Saltzman 2011; European Commission 2020).

\subsubsection{Mandatory or voluntary?}

In the last decades, there were many regulatory changes concerning non-financial reporting. Non-financial reporting started as a voluntary activity, currently there is a shift from voluntary regulation to public policy and governmental regulation. Since the beginning of this century, a growing number of countries introduced or strengthened mandated CSR reporting (KPMG et al. 2016). For the European Union the adoption of Directive 2014/95/EU that requires reporting of non-financial and diversity information by certain large companies is clear example. Maguire (2012) argued that voluntary reporting is a well-established trend 'prior to the implementation of state-mandated reporting guidelines'. In other words, mandatory regulation is a consequence of the voluntary attempts to report on non-financial indicators. Nowadays, both types of reporting exist next to each other, although regulatory pressure is increasingly seen as the instrument to improve CSR performance. Currently, several policies have a 'report or explain' approach, however the EU Non-financial reporting Directive straightforwardly requires reporting from organ- izations with more than 500 employees. It is claimed that roughly two thirds of the national reporting standards (in a selected sample of 30 countries with 140 national reporting standards in total) are mandatory (Hąbek and Wolniak 2013). The World Business Council for Sustainable Development argues that "more regulations can be expected as progressive businesses, governments and international standards setters acknowledge the role of corporate transparency in the transition to an inclusive and sustainable economy" (WBCSD 2014, p. 9).

Although there is a trend towards mandatory non-financial reporting, the positive effects of non-financial reporting are hampered by the differences in interpretation and use of the existing guidelines. Moreover, a more proactive non-financial report such as an integrated report is still voluntary in almost all countries. While there is some knowledge about assumed reasons for and assumed reasons against voluntary or mandatory non-financial reporting, knowledge about the real effects and impacts of both types of reporting is limited. Mandatory reporting seems to be intended for organizations to better account for their impacts on public goods and externalities, while voluntary reporting may be more oriented towards organizational benefits. However, it is difficult to validate these assumptions, as the impact of voluntary and mandatory non-financial reporting is a relatively new research topic and only limited evidence exists.

There are many arguments for and against mandatory and voluntary non-financial reporting (see for an overview of reasons Table 1). Organizations that report non-financial information all face challenges, whether the reporting is voluntary or mandatory. In both cases, different issues hamper the effectiveness of non-financial reporting. Research has shown both positive and negative effects of mandatory and voluntary non-financial reporting. Based on the academic research available, we have found positive (e.g. Hąbek and Wolniak 2013; Ioannou and Serafeim 2019) and negative arguments (e.g. Belkhir et al. 2017; Christensen et al. 2019) for mandatory and voluntary regulation on the organization and its stakeholders. It is much more difficult to provide a clear answer to the question if the implementation of mandatory non-financial reporting actually leads to improved performance. Such performance improvements were the stated objective of the introduction of the European Directive on non-financial disclosure as was communicated in the press release announcing the Directive: "Each individual company disclosing transparent information on social and environmental matters will realise significant benefits over time, including better performance, lower funding costs, fewer and less significant business disruptions, better relations with consumers and stakeholders. Investors and lenders will benefit from a more informed and efficient investment decision process. Society at large will benefit from companies managing environmental and social challenges in a more effective and accountable way" (European Commission 2014). Notably the 
societal benefits that are envisaged by the commission are so-called real effects of the NFI reporting mandate. To date empirical evidence for such effects is limited and often inconclusive. Chen et al. (2018) find some positive effects with respect to water and air pollution but others find no reductions for carbon reduction when reporting these emissions is mandatory (Matisoff 2013) or voluntary (Belkhir et al. 2017).

\section{From reporting to performance improvement}

\subsection{Transparency}

The essence of non-financial reporting goes beyond reporting. In general, we can argue that reporting increases transparency (e.g. Kolk 2004). However, researchers also argue that reporting might lead to reporting pitfalls, being idealistic reporting (showing a better picture than showing the truth), lay reporting (measuring only lagging indicators which are not helpful to improve performance), or technical reporting (providing only technical data but no data on processes or systems) (Baret and Helfrich 2019). Next to that, companies struggle to be transparent for stakeholders with different stakes, different needs and different expectations. Cho et al. 2015 (p. 81) argue that "organisations often respond to conflicting stakeholders demands", and thereby fall into "organized hypocrisy", which creates inconsistencies between an organisation's talk, decisions and actions. Furthermore, the compliance-driven logic underpinning the mandatory adoption of non-financial reporting may increase the risk of a "tick the box" approach, creating further inconsistencies between corporate talk and action (Adams 2015; La Torre et al. 2018).

Non-financial reporting is about creating benefits for the organization and its stakeholders by relating the reported information to business strategy. In result it is more a matter of management than reporting (Mammatt 2009) when it does not only give an explanation of the achieved non-financial performance (Eccles and Saltzman 2011) but also takes into account the future value for the organization, the stakeholders and society at large (Adams 2014). This is important for the company but also for its investors.

It is also argued that sustainability reporting can create more benefits for organizations, such as an increased stakeholder engagement (Krzus 2011; Eccles and Krzus 2010; Eccles and Saltzman 2011). This is important as the success and the value of an organization depend on its relationship with stakeholders (Cai et al. 2011). As previously mentioned, there is some evidence that non-financial reporting has positive links with (operating) performance. For example, Churet and Eccles (2014) found a strong relationship between ESG reporting and the financial performance of an organization. Similarly, Ioannou and Serafeim (2019) report increases in firm value measured in Tobin's Q due to mandatory CSR reporting.
Grewal et al. (2015) found a positive relation between financial market reaction and mandatory reporting. However, in general there is no conclusive evidence for the relation between business performance and non-financial reporting. In line with Guenther et al. (2015) there is evidence for some aspects that link to performance (such as waste or carbon emission). However, causality is hard to demonstrate because of the many factors influencing performance and more empirical research is needed to obtain a clearer picture of the actual results.

\subsection{Comparability}

Despite the growing interest in non-financial reporting, a report is only a means and not an end in itself. What matters most, are the consequences of these reports and the question whether the intended goals that are associated with non-financial reporting are achieved. Non-financial reporting will only be effective when the information provided is useful for internal and external stakeholders. In order to be useful non-financial information should meet qualitative characteristics that are similar to those of financial information. It needs to be relevant and faithfully (complete, neutral and free from errors) represent what it purports to represent (IASB 2019).

Metrics used in current sustainability reporting standards often lack validity or are based upon data that are most easily collected, rather than most important (Hess 2019). Moreover, the empirical evidence on sustainability reporting shows continued problems of selective disclosure, impression management, incomparable disclosures, and the use of disclosure as an end in itself (as opposed to a process that leads to organizational change) (Hess 2019). Despite the changed information need of stakeholders and the increased transparency of organizations related to non-financial information, research showed that investors have neither rewarded nor penalized organizations for violating matters ${ }^{2}$ in their corporate decisions (Christofi et al. 2012). More recently, Kim et al. (2018) found an effect of integrated reports on analyst earnings forecasts. As long as the existing guidelines for non-financial reporting contain weaknesses (e.g. unclear guidelines, non-comparability, not sector specific and not integrating business and sustainability) and there is lack of professionalism in the organization to use and implement the guidelines in a proper way, organizations and society cannot benefit from all potential advantages associated with non-financial reporting.

An underlying reason for this is the lack of comparability between sustainability reports. Increasingly, stakeholders are asking for comparable information. However, many organizations publish their non-financial information voluntarily or in accordance with requirements that offer wide discretion to management with respect to the content and form of the information provided. Different standards exist providing guidelines on how to report (1) outputs (e.g. GRI), (2) processes (e.g. Greenhouse Gas Protocol), and (3) impacts (e.g. true value reporting). The 
existence and use of these different standards, goes at the cost of a lack of comparability between sustainability reports (Barker and Eccles 2018; Eccles and Saltzman 2011; European Commission 2020). Moreover, the reported non-financial information is still often presented in a disconnected way. Its relationship to strategy, risks and opportunities, operations, and financial performance is often unclear (IFAC 2012). In addition, the content of current sustainability reports often lacks materiality ${ }^{3}$ and can be incomplete and selective (Van Wensen et al. 2011; Green and Cheng 2019). A focus on materiality implies limiting the information presented and reducing the number of metrics common across all organizations leading to less comparability of the reports.

\subsection{Performance Management}

Ramos et al. (2013) showed that organizations need to be more engaged with sustainability performance management as well as with reporting on sustainability issues. It is important to make organizations and their stakeholders aware of the importance of integrating the information on non-financial issues in performance management and management accounting and control systems (Maas et al. 2016). For example, in 2012 about $40 \%$ of the largest US firms included CSR targets in their bonus system (Maas 2018). In the Netherlands organizations like DSM and Akzo Nobel use CSR targets in their remuneration systems (Kolk and Perego 2014). Using non-financial information for internal goals is valuable for organizations as the focus of rating agencies shows that investors value sustainability management programs rather than absolute sustainability performance (McLaughin et al. 2015). As long as organizations do not integrate their non-financial information in management decisions, and do not use and learn from their non-financial information, non-financial reporting cannot be effective in improving performance - irrespective of whether it is mandatory or voluntary. However, when organizations use the non-financial information published in their reports to integrate in their management decisions, it can lead to sustainable value for society, ecosystems and business (Maas et al. 2016). In addition, the non-financial, sustainable information in the reports can be a source of innovation (Porter and Kramer 2006; Husted and De Jesus Salazar 2006; Hart and Milstein 2003).

\subsection{Performance Improvement and the importance of feedback loops}

One critical criterion to improve sustainability performance is to organize and use stakeholder feedback. Once the content of the report is clear, internal and/or external stakeholders can give advice, suggestions and criticism to the organization based on the report. Organizations can use this feedback in their decision-making and management processes. It is argued that it is valuable when a non-financial report considers not only sustainability performance outcomes, but information about the process towards these outcomes as well (WBCSD 2019). This enables stakeholders to provide feedback on this process, which is helpful for organizations to think about the relationship between (sustainability) performance and business strategy, business models, strategic programs and strategic objectives. Moreover, it is important that organizations report on medium and long-term targets. All these aspects enable the readers of the report and the stakeholders to see improvement in the organizations' performance and to give feedback. Based on this feedback, the organization can reconsider its decisions or improve its performance (WBCSD 2019).

In addition to the belief that stakeholder feedback is very important to inform organizations with respect to desirable changes it also provides an incentive to change. According to Deloitte and MVO Nederland (2015), external pressure from stakeholders is important because it works better than internal pressure.

\section{Conclusion}

Regulation is often seen as an adequate tool for improving corporate sustainability practices (Hąbek and Wolniak 2013; WBCSD 2019). The European Commission decided to implement a legislative proposal for non-financial reporting, because they believed there was a need to improve the disclosure of social and environmental information (European Commission 2014b). According to the website of the European Commission, "large public-interest entities (listed companies, banks, insurance undertakings and other companies that are so designated by Member States) with more than 500 employees should disclose in their management report relevant and useful information on their policies, main risks and outcomes, relating to several sustainability issues" (European Commission 2015). In order to meet those objectives the Dutch government has implemented the EU directive of non-financial reporting at the end of 2016.

In this study we analyzed the Theory of Change (ToC) behind non-financial reporting as well as the evidence base for its assumed effectiveness. The results show that the potential benefits of mandatory non-financial reporting strongly depend on context, the implementation and the organization. In Table 1, internal and external consequences of non-financial reporting on the organization and its stakeholders as found in available research is provided. Available research shows expected positive effects $(+)$ as well as negative effects (-) for organizations or stakeholders.

The principal aim of the European commission and the national implementation of the directive on non-financial reporting in the end is to limit negative externalities from organizations' actions, either within the Netherlands or through their supply chains abroad, and to improve organizations' performance on non-financial issues, using the internal and external feedback loops. This research shows that the ToC to achieve performance improvement by reporting is complex. Given the complexity and need to gather more 
Table 1. Overview of the effects and impacts (both positive and negative) of non-financial reporting.

\begin{tabular}{|c|c|c|}
\hline Non-financial reporting can lead to: & Reference & Effect / Impact \\
\hline Ability to manage reputational and organizational risks & Eccles and Saltzman 2011; Krzus 2011; Adams 2014 & + \\
\hline $\begin{array}{l}\text { Clear image of organization with information on future value of } \\
\text { organization }\end{array}$ & Adams 2014 & + \\
\hline Compliance & Hąbek and Wolniak 2013 & - \\
\hline \multirow[t]{3}{*}{ CSR performance } & Guenther et al. 2015; Chen et al. 2018 & + \\
\hline & Matisoff 2013 & - \\
\hline & Belkhir et al. 2017 & - \\
\hline Decision making without new mindset of manager & Adams 2014 & - \\
\hline High costs & Christensen et al. 2019 & - \\
\hline $\begin{array}{l}\text { Increased awareness in organization about their role in society and value } \\
\text { creation for stakeholders }\end{array}$ & Kolk 2004; Adams 2014 & + \\
\hline Innovation & $\begin{array}{l}\text { Porter and Kramer 2006; Husted and De Jesus Salazar 2006; Hart and } \\
\text { Milstein } 2003\end{array}$ & + \\
\hline Long-term vision & Eccles et al. 2012 & + \\
\hline Operating/financial performance & $\begin{array}{l}\text { Guenther et al. 2015; Grewal et al. 2015; Churet and Eccles 2014; } \\
\text { Ioannou and Serafeim } 2014\end{array}$ & + \\
\hline Successful decision making & $\begin{array}{l}\text { Krzus 2011; IIRC 2012; Eccles and Krzus 2010; Prado-Lorenzo and } \\
\text { Garcia-Sachez 2010) }\end{array}$ & + \\
\hline $\begin{array}{l}\text { Relation between financial and non-financial information (good for } \\
\text { management) }\end{array}$ & Eccles and Saltzman 2011; Mammatt 2009 & + \\
\hline Uncertain chance of success & Adams 2014 & - \\
\hline \multirow[t]{2}{*}{ Comparability } & Jeffrey and Perkins 2014 & + \\
\hline & $\begin{array}{l}\text { Maas et al. 2014, Eccles and Saltzman 2011; Eccles et al. 2012; Barker } \\
\text { and Eccles 2018; EU 2020; Christensen et al. 2019; De Cambour et al. } \\
\text { 2019; Swift 2001 }\end{array}$ & - \\
\hline Confusion concerning ESG indicators & $\begin{array}{l}\text { Eccles et al. 2012; Van Wensen et al. 2011; Eccles and Saltzman 2011; } \\
\text { Cheng et al. } 2014\end{array}$ & - \\
\hline Corporate branding & Lindgreen and Swaen 2010 & + \\
\hline $\begin{array}{l}\text { Disconnection between strategy, risks and opportunities, operations, and } \\
\text { financial performance }\end{array}$ & IFAC 2012 & - \\
\hline \multirow[t]{2}{*}{ Financial market reaction } & $\begin{array}{l}\text { Grewal et al. 2015; Churet and Eccles 2014; Kim et al. 2019; Ioannou and } \\
\text { Serafeim } 2014\end{array}$ & + \\
\hline & Christofi et al. 2012 & - \\
\hline Improved competitive position & Eccles and Krzus 2010 & + \\
\hline Improved firm reputation & Maas 2009; Kolk 2004; Bebbington et al. 2008 & + \\
\hline Incomplete and selective information & $\begin{array}{l}\text { Van Wensen et al. 2011; Eccles and Serafeim 2011; Cheng et al. 2014; } \\
\text { Kamp-Roelands 2011; Wallage } 2011\end{array}$ & - \\
\hline Increased credibility & Kolk 2004 & + \\
\hline Increased stakeholder engagement, dialogue and/or satisfaction & $\begin{array}{l}\text { Maas 2009; IIRC 2011; Krzus 2011; Eccles and Krzus 2010; Eccles and } \\
\text { Saltzman 2011; GRI 2002 }\end{array}$ & + \\
\hline Increased transparency & Kolk 2004; IIRC 2013 & + \\
\hline Lack of materiality & Green and Cheng 2019 & - \\
\hline $\begin{array}{l}\text { Lack of validity or based upon data that is most easily collected, rather } \\
\text { than most important }\end{array}$ & Hess 2019 & - \\
\hline $\begin{array}{l}\text { Reporting pitfalls like reporting hypocrisy, idealistic reporting and } \\
\text { 'ticking the box' }\end{array}$ & Adams 2015; La Torre et al. 2018; Baret and Helfrich 2019; Cho et al. 2015 & - \\
\hline
\end{tabular}

evidence, being clear and explicit about the long-term ambition of enforcing non-financial reporting is needed.

In the last decennia we have seen an increase of reporting on non-financial information. However, there is still a large group of laggards that do not yet report on non-financial information. Although reporting is evolving towards a more integrated approach, many organizations still struggle to adopt such an integrated approach. Organizations could benefit from more guidance to how to report in an integrative way and about what to report. Existing research shows positive and negative effects on the impacts of non-financial disclosure. It is clear that more practical information and research on the actual impacts of reporting is needed. The expectation that reporting will automatically lead to improved performance is not as straightforward as it might seem. Future research might focus on the impact of reporting on performance improvements and the indirect effects on external stakeholders.

- Prof. dr. K.E.H. Maas, Professor of Accounting \& Sustainability, Department of Accounting and Finance, Open University, Heerlen, and Impact Centre Erasmus, Erasmus University Rotterdam.

- Prof. dr. P.A.M. Sampers, Professor of Financial Accounting, Department of Accounting and Finance, Open University, Heerlen, and Department of Accounting \& Information Management, Maastricht University, Maastricht.

- The authors acknowledge the commission of PBL Netherlands Environmental Agency. Thanks also to Marjelle Vermeulen for her contribution to this literature review. 


\section{Notes}

1. With non-financial reporting we refer to all different types of non-financial, environmental and/or sustainability reporting or disclosure, such as a separate sustainability report, a combined annual and sustainability report or the most recent trend in non-financial reporting, an Integrated Report (IR). Consequently, we will use both the terms non-financial reporting and sustainability reporting.

2. Examples of violating matters are environmental and social violations, such as the violations of human rights, or violations of voluntary target setting (e.g. CO2 reduction in a specific year).

3. Materiality refers to the importance and the usefulness of a report. Material issues are those issues that substantively impact, or have the potential to substantively impact the company's strategy and its ability to create value over the short, medium and long term.

\section{References}

- Adams CA (2015) The international integrated reporting council: a call to action. Critical Perspectives on Accounting 27: 23-28. https://doi.org/10.1016/j.cpa.2014.07.001

- Baret P, Helfrich V (2019) The "trilemma" of non-financial reporting and its pitfalls. Journal of Management and Governance 23(2): 485-511. https://doi.org/10.1007/s10997-018-9430-z

- Barker R, Eccles RG (2018) Should FASB and IASB be responsible for setting standards for non-financial information? Green paper. Said Business School. https://doi.org/10.2139/ssrn.3272250

- Bebbington J, Larrinaga C, Moneva JM (2008) Corporate social reporting and reputation risk management. Accounting, Auditing \& Accountability Journal 21(3): 337-361. https://doi. org/10.1108/09513570810863932

- Belkhir L, Bernard S, Abdelgadir S (2017) Does GRI reporting impact environment sustainability? A cross-industry analysis of $\mathrm{CO}_{2}$ emissions performance between GRI-reporting and non-reporting companies. Management of Environmental Quality 28(2): 138-155. https://doi.org/10.1108/MEQ-10-2015-0191

- Bernow S, Godsall J, Klempner B, Merten C (2019) More than values: The value-based sustainability reporting that investors want. McKinsey \& Company. https://www.mckinsey.com/business-functions/sustainability/our-insights/more-than-values-the-value-based-sustainability-reporting-that-investors-want\#

- Cai Y, Jo H, Pan C (2011) Vice or virtue? The impact of corporate social responsibility on executive compensation. Journal of Business Ethics 104: 159-173. https://doi.org/10.1007/s10551-011-0909-7

- Chen Y-C, Hung M, Wang Y (2018) The effect of mandatory CSR disclosure on firm profitability and social externalities: Evidence from China. Journal of Accounting and Economics 65: 169-190. https://doi.org/10.1016/j.jacceco.2017.11.009

- Cheng M, Green W, Conradie P, Konishi N, Romi A (2014) The international integrated reporting framework: Key issues and future research opportunities. Journal of International Financial Management \& Accounting 25(1): 90-119. https://doi.org/10.1111/ jifm. 12015

- Cho CH, Laine M, Roberts RW, Rodrigue M (2015) Organized hypocrisy, organizational façades, and sustainability reporting. Accounting, Organizations and Society 40: 78-94. https://doi. org/10.1016/j.aos.2014.12.003

- Christensen HB, Hail L, Leuz C (2019) Adoption of CSR and sustainability reporting standards: economic analysis and review. NBER working paper series, 26169. https://doi.org/10.3386/w26169

- Christofi A, Christofi P, Sisaye S (2012) Corporate sustainability: historical development and reporting practices. Man- agement Research Review 35(2): 157-172. https://doi. org/10.1108/01409171211195170

- Churet C, Eccles RG (2014) Integrated reporting, quality of management, and financial performance. Journal of Applied Corporate Finance 26(1): 56-64. https://doi.org/10.1111/jacf.12054

- Clark C, Rosenzweig W, Long D, Olsen S (2004) Double bottom line project report: Assessing social impact in double bottom line ventures. Methods catalog. Columbia Business School, New York. https://centers.fuqua.duke.edu/case/wp-content/uploads/ sites/7/2015/02/Report_Clark_DoubleBottomLineProjectReport_2004.pdf

- Commission of the European Communities (2002) Corporate Social Responsibility: A business contribution to sustainable development COM(2002) 347 final; Brussels: CEC. https://eur-lex.europa.eu/ LexUriServ/LexUriServ.do?uri=COM:2002:0347:FIN:EN:PDF

- De Cambourg P, Gardes C, Viard V (2019) Ensuring the relevance and reliability of non-financial corporate information: an ambition and a competitive advantage for a sustainable Europe. Research report, Authorité des normes comptables. http://www.anc.gouv.fr/ files/live/sites/anc/files/contributed/ANC/4.\%20Qui\%20sommesnous/Communique_de_presse/Report-de-Cambourg_extra-financial-informations_May2019_EN.pdf

- Deloitte, MVO Nederland (2015) Integrated reporting as a driver for integrated thinking? Maturity of $<\mathrm{IR}>$ in the Netherlands. https://www2.deloitte.com/content/dam/Deloitte/nl/Documents/risk/ deloitte-nl-risk-integrated-reporting-a-driver-for-integrated-thinking. pdf

- Eccles RG, Ioannou I, Serafeim G (2012) The Impact of a Corporate Culture of Sustainability on Corporate Behaviour and Performance. (No. 12-035). Harvard Business School, Boston. https:/www.hbs. edu/faculty/Publication\%20Files/SSRN-id1964011_6791edac7daa-4603-a220-4a0c6c7a3f7a.pdf

- Eccles RG, Krzus MP (2010) One Report: Integrated Reporting for a Sustainable Strategy. John Wiley \& Sons.

- Eccles RG, Saltzman D (2011) Achieving sustainability through integrated reporting. Stanford Social Innovation Review (Summer 2011): 56-61. https://ssir.org/articles/entry/achieving_sustainability_through_integrated_reporting

- Eccles RG, Serafeim F (2011) Accelerating the adoption of integrated reporting. In: De Leo F, Vollbracht M (Eds) CSR Index 2011: 70-92. https://www.hbs.edu/faculty/Pages/item.aspx?num=40841

- European Commission (2014a) Richtlijn 2014/95/EU van het Europees Parlement en de Raad van 22 oktober 2014 tot wijziging van Richtlijn 2013/34/EU met betrekking tot de bekendmaking 
van niet-financiële informatie en informatie inzake diversiteit door bepaalde grote ondernemingen en groepen. http://eur-lex. europa.eu/legal-content/EN/ALL/?uri=CELEX:32014L0095\&qid=1430238231690

- European Commission (2014b) Disclosure of non-financial and diversity information by large companies and groups-frequently asked questions. https://ec.europa.eu/commission/presscorner/detail/en/ MEMO_14_301

- European Commission (2015) Non-financial reporting. http://ec.europa.eu/finance/company-reporting/non-financial_reporting/index_ en.htm\#related-documents-preparatory

- European Commission (2020) Consultation document review of the non-financial reporting directive. https://ec.europa.eu/info/sites/ info/files/business_economy_euro/company_reporting_and_auditing/documents/2020-non-financial-reporting-directive-consultation-document_en.pdf

- Frias-Aceituno JV, Rogdríguez-Ariza L, Garcia-Sánchez IM (2013) Is integrated reporting determined by a country's legal system? An exploratory study. Journal of Cleaner Production 44: 45-55. https://doi. org/10.1016/j.jclepro.2012.12.006

- García-Sánchez IM, Rodríguez-Ariza L, Frías-Aceituno JV (2013) The cultural system and integrated reporting. International Business Review 22(5): 828-838. https://doi.org/10.1016/j.ibusrev.2013.01.007

- Gray R, Owen D, Maunders KT (1988) Corporate social reporting: Emerging trends in accountability and the social contract. Accounting, Auditing \& Accountability Journal 1(1): 6-20. https://doi. org/10.1108/EUM0000000004617

- Grayson D, Hodges A (2004) Corporate Social Opportunity!: Seven Steps to Make Corporate Social Responsibility Work for your Business. Greenleaf Publishing, London.

- Grewal J, Riedl EJ, Serafeim G (2015) Market reaction to mandatory nonfinancial disclosure. Management Science 65(7): 3061-3084. https://doi.org/10.2139/ssrn.2657712

- GRI (Global Reporting Initiative) (2002) Sustainability reporting guidelines 2002. www.globalreporting.org

- Green WJ, Cheng MM (2019) Materiality judgments in an integrated reporting setting: The effect of strategic relevance and strategy map. Accounting, Organizations and Society 73: 1-14. https://doi. org/10.1016/j.aos.2018.07.001

- Guenther E, Guenther T, Schiemann F, Weber G (2015) Stakeholder relevance for reporting explanatory factors of carbon disclosure. Business \& Society 55(3): 361-397. https://doi. org/10.1177/0007650315575119

- Hąbek P, Wolniak R (2013) European Union regulatory requirements relating to sustainability reporting. The case of Sweden. Zeszyty Naukowe/Akademia Morska w Szczecinie 34(106): 40-47. https://pdfs.semanticscholar.org/9764/a423e81f667ef56a27fde6d6e11a127eab90.pdf

- Hart SL, Milstein MB (2003) Creating sustainable value. Academy of Management Perspectives 17(2): 56-67. https://doi.org/10.5465/ ame.2003.10025194

- Hess D (2019) The transparency trap: Non-financial disclosure and the responsibility of business to respect human rights. American Business Law Journal 56(1): 5-53. https://doi.org/10.1111/ ablj.12134

- Husted BW, De Jesus Salazar J (2006) Taking Friedman seriously: Maximizing profits and social performance. Journal of Man- agement Studies 43(1): 75-91. https://doi.org/10.1111/j.14676486.2006.00583.x

- IASB (International Accounting Standards Board) (2019) Conceptual framework for financial reporting. London. https://www.ifrs.org/ issued-standards/list-of-standards/conceptual-framework/

- IFAC (International Federation of Accountants) (2012) Investors demand for environmental, social, and governance disclosures: implications for professional accountants in business. New York. https:/www.ifac.org/about-ifac/professional-accountants-business/ publications/investor-demand-environmental-social-and-governance-disclosures

- IIRC (International Integrated Reporting Committee) (2011) Towards integrated reporting. Communicating value in the $21^{\text {st }}$ Century. https://integratedreporting.org/wp-content/uploads/2011/09/ IR-Discussion-Paper-2011_spreads.pdf

- IIRC (International Integrated Reporting Committee) (2013) The International $<\mathrm{IR}>$ Framework. https://integratedreporting.org/resource/international-ir-framework/

- Ioannou I, Serafeim G (2019) The consequences of mandatory corporate sustainability reporting: evidence from four countries. In: McWilliams A, Rupp DE, Siegel DS, Stahl GK, Waldman DA (Eds) The Oxford Handbook of Corporate Social Responsibility: Psychological and Organizational Perspectives. Oxford University Press, Oxford, 452-489. https://doi.org/10.1093/oxford$\mathrm{hb} / 9780198802280.013 .20$

- Jeffrey C, Perkins JD (2014) Developing corporate reporting in the public interest: The question of mandatory CSR reporting and the potential for its Integration with financial reporting. In: Mintz S (Ed.) Accounting for the Public Interest. Advances in Business Ethics Research. A Journal of Business Ethics Book Series (Vol. 4). Springer, Dordrecht, 177-200. https://doi.org/10.1007/978-94-007-7082-9_9

- Jordan GB (2010) A theory-based logic model for innovation policy and evaluation. Research Evaluation 19(4): 263-273. https://doi.org $/ 10.3152 / 095820210 X 12827366906445$

- Kamp-Roelands N (2011) Integrated reporting en assurance. Maandblad voor Accountancy en Bedrijfseconomie 85(11): 552 561. https://doi.org/10.5117/mab.85.12868

- Keeble JJ, Topiol S, Berkeley S (2003) Using indicators to measure sustainability performance at a corporate and project level. Journal of Business Ethics 44: 149-158. https://doi. org/10.1023/A:1023343614973

- Kim S, Maas K, Perego P (2018) The effect of publication, format and content of Integrated Reports on analysts' earnings forecasts. In: Boubaker S, Cumming D, Nguyen DK (Eds) Research Handbook of Finance and Sustainability, chapter 28. Edward Elgar Publishing, Cheltenham, 550-572. https://doi.org/10.4337/9781786432636

- King ME (2011) Integrated Reporting - a concept whose time has come. Maandblad voor Accountancy en Bedrijfseconomie 85(11): 535-536. https://doi.org/10.5117/mab.85.12864

- Kolk A (2004) A decade of sustainability reporting: developments and significance. International Journal of Environment and Sustainable Development 3(1): 51-64. https://doi.org/10.1504/ IJESD.2004.004688

- Kolk A, Perego P (2014) Sustainable bonuses: sign of corporate responsibility or window dressing? Journal of Business Ethics 119(1): 1-15. https://doi.org/10.1007/s10551-012-1614-x

- KPMG, GRI, UNEP \& CCGA (2016) Carrots \& Sticks. Global trends in sustainability reporting regulation and policy. https:// 
assets.kpmg/content/dam/kpmg/pdf/2016/05/carrots-and-sticksmay-2016.pdf

- Krzus MP(2011) Integrated reporting: if not now, when? IRZ-Zeitschrift für Internationale Rechnungslegung 6: 271-276. https://pdfs.semanticscholar.org/33a4/3eb8890684ef14b8efc0bb49fcf61971d8f8.pdf

- La Torre M, Sabelfeld S, Blomkvist M, Tarquinio L, Dumay J (2018) Harmonising non-financial reporting regulation in Europe: Practical forces and projections for future research. Meditari Accountancy Research 26(4): 598-621. https://doi.org/10.1108/MEDAR-02-2018-0290

- Liket KC, Rey-Garcia M, Maas KEH (2014) Why aren't evaluations working and what to do about it: A framework for negotiating meaningful evaluation in nonprofits. American Journal of Evaluation 35(2): 171-188. https://doi.org/10.1177/1098214013517736

- Lindgreen A, Swaen V (2010) Corporate social responsibility. International Journal of Management Reviews 12(1): 1-7. https://doi. org/10.1111/j.1468-2370.2009.00277.x

- Lozano R (2013) Sustainability inter-linkages in reporting vindicated: a study of European companies. Journal of Cleaner Production 51: 57-65. https://doi.org/10.1016/j.jclepro.2013.01.039

- Maas KEH (2018) Do corporate social performance targets in executive compensation contribute to corporate social performance? Journal of Business Ethics 148(3): 573-585. https://doi.org/10.1007/ s10551-015-2975-8

- Maas KEH (2011) Maatschappelijke prestaties van organisaties: van outputmeting naar impactmeting. Maandblad voor Accountancy en Bedrijfseconomie 85(11): 563-572. https://doi.org/10.5117/ mab.85.12870

- Maas K, Boons F (2010) CSR as a strategic activity. Value creation, redistribution and integration. In: Louche $\mathrm{C}$, Idowu SO, Leal Filho W (Eds) Innovative CSR. Greenleaf Publishing, Sheffield, 154-172. https://doi.org/10.4324/9781351279000-8

- Maas KEH, Liket KC (2012) Social impact measurement: classification of methods. In: Burritt R, Schaltegger S, Bennett M, Pohjola T, Csutora M (Eds.) Environmental Management Accounting and Supply Chain Management. Eco-Efficiency in Industry and Science (Vol. 27). Springer, Dordrecht, 171-202. https://doi. org/10.1007/978-94-007-1390-1_8

- Maas K, Schaltegger S, Crutzen N (2016) Integrating corporate sustainability assessment, management accounting, control, and reporting. Journal of Cleaner Production 136 (Part A): 237-248. https://doi. org/10.1016/j.jclepro.2016.05.008

- Maas KEH, Vermeulen MC (2015) A systemic view on the impacts of regulating non-financial reporting. Erasmus School of Economics, Rotterdam. https://www.eur.nl/en/ice/media/2020-06-pbl-rapport0

- Maguire M (2012) From private regulation to public policy: the case of corporate non-financial reporting. Evolution of responsible investment: navigating complexity. PRI-CBERN Academic Network Conference 2012 (Toronto): 1-23. https://carleton.ca/3ci/2012/ pri-cbern-academic-network-conference-october-1-3-2012-evolution-of-responsible-investment-navigating-complexity-2/

- Mammatt J (2009) Integrated sustainability reporting and assurance. Conference Proceedings of the CIS Corporate Governance Conference Held in Johannesburg. http://www.chartsec.co.za/documents/ speakerPres/JayneMammat/MammattIntegratedSustainabilityReportingandAssurance.pdf
- Matisoff D (2013) Different rays of sunlight: understanding information disclosure and carbon transparency. Energy Policy 55: 579592. https://doi.org/10.1016/j.enpol.2012.12.049

- McLaughin G, Van der Kruijf A, Van Dijk A (2015) Biodiversity in the spotlight? Assessing the coverage and quality of reporting on the issues of land use, biodiversity, water and product sustainability by companies worldwide. Sustainalytics, Amsterdam.

- Porter ME, Kramer MR (2006) Strategy and society: The link between competitive advantage and corporate social responsibility. Harvard Business Review 84(12): 78-92. [Reprint R0612D]

- Prado-Lorenzo JM, García-Sánchez IM (2010) The role of the board in disseminating relevant information on greenhouse gases. Journal of Business Ethics 97(3): 391-424. https://doi.org/10.1007/s10551010-0515-0

- Ramos TB, Cecílio T, Douglas CH, Caeiro S (2013) Corporate sustainability reporting and the relations with evaluation and management frameworks: the Portuguese case. Journal of Cleaner Production 52: 317-328. https://doi.org/10.1016/j.jclepro.2013.03.002

- Schaltegger S, Hörisch J, Freeman RE (2019) Business cases for sustainability: A stakeholder theory perspective. Organization \& Environment 32(3): 191-212. https://doi. org/10.1177/1086026617722882

- Swift T (2001) Trust, reputation and corporate accountability to stakeholders. Business Ethics: A European Review 10(1): 16-26. https://doi.org/10.1111/1467-8608.00208

- Van der Esch S, Steurer N (2014) Comparing public and private sustainability monitoring and reporting. PBL Netherlands Environmental Assessment Agency. https://www.pbl.nl/en/publications/comparing-public-and-private-sustainability-monitoring-and-reporting

- Van Wensen KV, Broer W, Klein J, Knopf J (2011). The state of play in sustainability reporting in the European Union. Publication commissioned under the European Union's Programme for employment and social solidarity-progress (2007-2013). Amsterdam, Berlin. https://www.somo.nl/wp-content/uploads/2011/04/ The-State-of-Play-in-Sustainability-Reporting-in-the-European-Union.pdf

- Wainwright S (2002) Measuring impact: A guide to resources. NCVO Publications, London.

- Wallage P (2011) Naar een geïntegreerde verslaggeving - Voor elck wat wils. Maandblad voor Accountancy en Bedrijfseconomie 85(11): 543-551. https://doi.org/10.5117/mab.85.12867

- WBCSD (World Business Council for Sustainable Development) (2014) Reporting matters. Improving the effectiveness of reporting one year on. Geneva. http://docs.wbcsd.org/2014/11/WBCSD_Reporting_Matters_2014_Interactive.pdf

- WBCSD (World Business Council for Sustainable Development) (2019) Reporting matters. Navigating the landscape: a path forward for sustainability reporting. Geneva. https://www.wbcsd.org/Programs/Redefining-Value/External-Disclosure/Reporting-matters/ Resources/Reporting-matters-2019

- WCED (World Commission on Environment and Development) (1987) Our common future. Oxford University Press, Oxford. https:// sustainabledevelopment.un.org/content/documents/5987our-common-future.pdf 